\title{
25. Mainzer Allergie-Workshop in Bildern
}
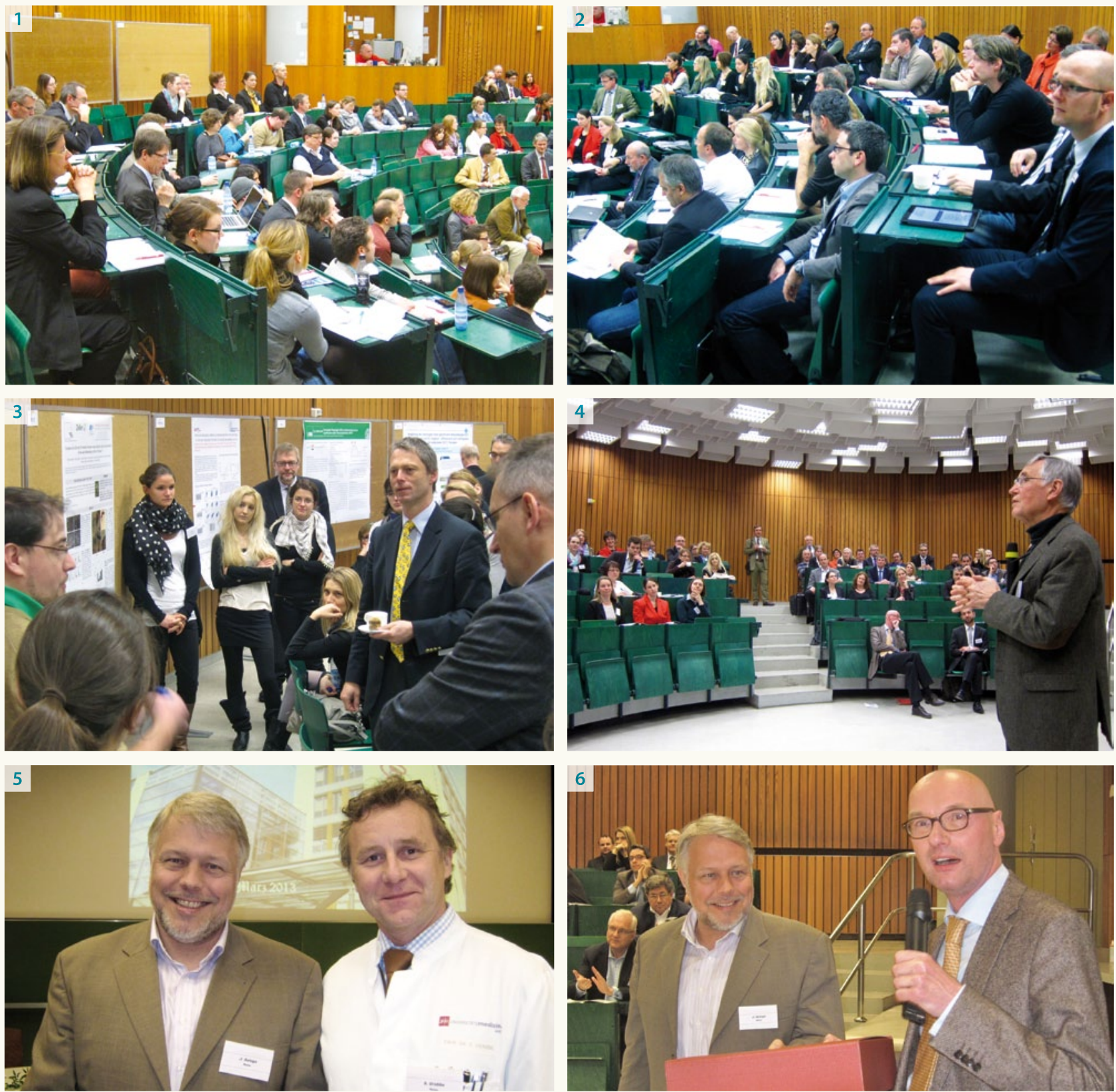

Abb. 1 + Abb. 2: Vollbesetzter Hörsaal und interessierte Teilnehmer bis zur letzten Bank

Abb. 3: Konstruktiver Austausch an den wissenschaftlichen Postern: neue Daten in der Diskussion

Abb. 4: Prof. Dr. Jürgen Knop (Emeritus der Mainzer Universitäts-Hautklinik) beim Jubiläumsvortrag und Blick über den Tellerrand: von der Wissenschaftskrise zur holistischen Weltbetrachtung

Abb. 5: Freundliche Gastgeber der jährlichen allergologischen DGAKI-Frühjahrstagung: Prof. Dr. Joachim Saloga (links) und Prof. Dr. Stephan Grabbe (rechts)

Abb. 6: Prof. Dr. Joachim Saloga (links), seit über 20 Jahren Motor des Mainzer Allergie-Workshops, empfängt die „Rote Box“ von DGAKI-Präsident Prof. Dr. Harald Renz (rechts) zum 25. Jubiläum der DGAKI-Frühjahrstagung: wohlverdiente Anerkennung für kollegiales Engagement und die erfolgreiche Organisation im Team. 